\title{
Research On The Humanities Of Ideological And Political Education
}

\author{
Pei $\operatorname{Han}^{1, a}$ \\ ${ }^{1}$ Harbin University of Science and Technology, Harbin, China; \\ a349376428@qq.com
}

Keywords:ideological and political education, humanity, research.

\begin{abstract}
Human being is the social practice object of ideological and political education, according to the development law of people's ideological and moral character, which has impacts on their ideological and spiritual world.There is no doubt, the ideological and political education possesses humanistic character. At present, the research on the humanities of ideological and political education is relatively scarce, lacking of the theorized and systematized. My opinions about the research of the ideological and political education's humanities should trace its origin , Starting with the teleology of ideological and political Education, focusing on the humanistic studies of the fundamental purpose, the cultivation goal and the main tasks of the ideological and political education. Researching the humanity of the ideological and political education is conducive to excavate its breadth and depth, broadening the field of ideological and political education,so as to promote the ideological and political education, scientific and universal development.
\end{abstract}

\section{The Humanistic Study Of The Fundamental Purpose Of Ideological And Political Education}

The fundamental purpose of the ideological and political education is to improve abilities about knowing and changing the objective world, and can transform the subjective world while transforming the objective world. Existence with object relationship between people and the substantial world are mainly manifested in four aspects, including human and nature, human and others, human and groups, human and history, in every cor-relativity of man and the substantial world,containing true, goodness and beauty, which is opposite to the humanities.

Human and Nature.The ecological view of ideological and political education putting forward with the emergence of the relationship between human and nature., it is the basic thoughts to guide people knowing and transforming the nature, and its core is the understanding of the relationship between human and nature.In the process of material exchange with nature, human beings gradually recognize the objective world, then transform the objective world and simultaneously make harmonious development between the subjective world and the objective world. It can be said that the ideological and political education is a kind of world view, which is the basic understanding and basic point of view of the relationship between human and nature. From Confucian "the nature and man unites as one", Taoism "identity of object and subject "to Buddhist " all things are equal ", all these highlight coequal of human and nature. To live in harmony, human beings should explore the law of nature and the truth of natural science by the basis of practice. The ecological view of ideological and political education is also a kind of values. In the process of transforming nature, human being is inevitable in conflict with nature, and it is very essential to regulate people's behavior by what kind of value.Marxism believed that the fundamental way to solve the problem of ecological environment is to establish an ideal society, to completely reverse capitalism alienation on material interests relationship between human and nature.It is said that human beings should 
abandon interests of the supreme principle in the process of transforming the nature, and should adhere the principle of harmony with nature. The ecological view of ideological and political education is also a kind of civilization view. The essence of the ecological civilization is the harmonious development of human and nature. Marxism argued that, man is a part of nature, the harmony between man and nature is the harmony of mankind itself. Long ago, harmonious relations between human and nature created beauty,such as the ancient Egyptians praise the Nile, the Chinese praise ancient Yellow River Basin, the beauty of Pythagoras golden section law. The contemporary with Scientific Development, putting forward the theory of ecological civilization construction, the beautiful China will cast a thousand beams.

Human and Others. An important purpose of ideological and political education is to build a harmonious relationship between people and people, namely, via the sincere exchanges, discovering the beauty of human kind. In real life, how to deal with the different needs of interest subjects is the key to the ideological and political education to play the social function. So in dealing with the relationship between human and others,people should adhere to the Marx doctrine of interpersonal communication. Marx, Engels thinks that :"the universal existence form of human being and the human society is the communication activity , and human survival and development must rely on others, then people through communication obtain a kind of social property." [1]One is the sum of all social relations,and social attributes make people know the reason why people need to interact with others, and in the communication people can achieve personal interests.Marx said, "the correct understanding of the individual interests is the basis of the whole moral."[2]Therefore, even if the political science believed that: the relationship between man and man is of interest, the maintenance of the interests relations still needing good faith, kind, nice and other moral foundations.

Human and Groups. Group and individual is relative, which is individual community. Different individuals according to certain characteristics together for activities lead to the formation of the group. For example, the primitive society, human beings combined together in order to survive, the common food, the common enemy, the common breeding offspring, forming the biological characteristics of the group.With the development of society, the relationship between groups and politics, economy, culture and so on are getting closer and closer. Individuals often through group activities participate in social life and become the purpose of social members, to get a sense of security, responsibility, family, friendship, care and support in the community. People always belong to a certain social group, and life is always true in particular family, community, region, class, stratum, social groups,nation state. Resulting in different levels of social groups for their subordinate cognition, the cognitive is to explore and introspect the truth. Regarding the group as a whole, the individual as a part, the whole is made up of parts. When part of the overall structure of the formation is reasonable, the overall function will be greater than the function of the parts. At this time, the group's positive function is highlighted. Human resides in groups, under the function of group cohesion, guiding role and inheritance of social culture, harvesting the true, the goodness and the beauty, and can adjust and resolve social conflicts, maintenance of harmonious society, promoting the political, economic and cultural development.

Human and History. The ideological and political education advocates that using Marx's historical view regards the relationship between man and history.Marx made it clear,"the first premise of all human history is undoubtedly the existence of the life of the individual."[3]History has its own laws of development, but people can play the subjective initiative, from historical events, historical figures and other aspects of history. In the relationship between human and history, there exists cognitive relationship (true), practical relationship (goodness), aesthetic relationship (beauty). The cognitive relationship between man and history is mainly reflected in the 
understanding of historical facts and the understanding of the law of historical development.It is not easy to know the facts and laws of history,"We are going to against the history as only the emperors laurels, and compulsory authenticity obey the principles of ethical pan moral-ism".[4]Social history is the objective law of the dialectical development process, so people have to truly restore the historical appearance.The general trend of history is moving forward,only does people cognitive history,then can draw lessons from history, which can guide human practice and aesthetics. In the specific historical conditions, promoting material civilization development and spiritual civilization development of the historical practice, for to reproduce the style of art history, the concept of aesthetics (such as "tragedy", "comedy", "drama", "epic") into the contribution to the study of history should be inherited and carried forward.In the long river of human and history, True, good, beauty like running water, stretches a long, flowing.

\section{The Humanistic Study On The Cultivation Goal Of Ideological And Political Education}

The goal of Ideological and political education is to promote and implement the all-round development of human beings. Adhering to the all-round development of human beings should overcome partiality, and should break through the barriers of " ethical man ", " divine man ", " economic man " ,and " tool man " , to be a person who is completed and focused. The all-round development of human beings Marx referred, which includes the individuals ability of work (including physical and intellectual) development well, the multifaceted development of people's talent and quality, the enrichment and development of human society, as well as the coordinated development of man and society. The all-round development of human beings is a dynamic process, and the essence is human's subjective consciousness continuing to strengthen, which is the subjectivity of people continuous rising, which is the ability to work continuously improvement, which is the social relations constantly improvement, which is the process of comprehensive quality constantly improvement. Marx's thought on the all-round development of human beings is the unification of the practice view and history view, the unification of human being(society) and nature, the unification of mankind in general and the individual, the unification of material civilization, political civilization, spiritual civilization, and ecological civilization, the unification of true (epistemology), good (ethics) and beauty (aesthetics).

To promote the all-round development of people needs to expand the educational function and development function of the ideological and political education. To achieve educational function, which is the fundamental function of ideological and political education, we can train and improve people's quality of ideological and political. Development function,which is an extension of education functions, by ideological and political education can tap into his personnel's potential and can give the fullest play to their initiative. The development function and education function of ideological and political education is guided by the Marxist theory on the all-round development of human beings, which is the ideological and moral formation and development of the use of the law, which is also the basic embodiment of the ideological and political education of humanity.

\section{The Humanistic Study Of The Main Tasks Of Ideological And Political Education}

The purpose of ideological and political education is through various stages and tasks of the ideological and political education to achieve. The main task of the ideological and political education is taking the ideal and belief education as the core, with an emphasis on patriotism education, basing on moral education, cultivating scientific ways of thinking.

Ideal and Belief Education is The Core. The Central Committee of the Communist Party of China, the State Council to the promulgation of the < on Further Strengthening and improving the ideological and political education of college students views $>$,"under the new situation how to further strengthen the ideological and political education for the full deployment, emphasizing that 
the ideal and belief education is the core of ideological and political education ."[5]

Ideal and belief education is a process that the ruling classes of the society through a variety of means for transmission his political ideas to members of the community and makes it become a common ideological basis of society members and behavior basis. Of course, understanding the ideal and belief education should pay attention to three points: first, talking about the ideal and faith education can not only one-sided emphasis on the future of the ambitious pursuit and realization, and ignoring the belief that people should uphold in the present life. Second, the ideal education should be combined with the reality. Third, through the education of faith, the belief is internalized into excellent quality.

Ideal and belief education is always through the lifeline of our Party in the ideological and political work. Strengthening the socialist ideals and beliefs, taking the Marxism Leninism, Mao Zedong Thought, Deng Xiaoping Theory and the important thought of "Three Represents" as a guide, in close to connect with the reality of building a well-off society in an all-round way, the ideal and faith education as the core, ideological and moral construction as the basis, all-round development as the goal, emancipating the mind, seeking truth from facts and keeping pace with the times, close to reality, close to life, upholding the people-oriented, is the central content of the ideological construction, and is the essential mission of the ideological and political education.

Patriotism Education is The Key. Patriotism is the glorious traditions of China, not only the most profound historical emotion, but also the spiritual of the Chinese people of all ethnic groups together, and it inspire and motivate the people of all nationalities having one heart. In the current construction of a well-off society in an all-round way, facilitating the socialist material civilization, spiritual civilization, political civilization, promoting comprehensive, coordinated and sustainable economic and social development, to carry forward and cultivate the spirit of patriotism is the needs to enhance national cohesion,national competitiveness ,individual ideological and moral qualities. <The citizen moral reconstruction implementation > pointed out, "every citizen should have the legal obligation and moral responsibility. The patriotism emphasis on the patriotic education in the whole process of citizen moral construction. The main content of patriotism education is to improve the national self-esteem, self-confidence and a sense of pride, proud of patriotic, ashamed of damage, the interests of the state and national dignity."[6]

Patriotism education in the new situation is mainly reflected in the following three aspects of the action. First, we should focus on political fate of the motherland, the development direction, which is the center of the patriotic thought content. Second, we should have the duty for our country. The people should share the sense of responsibility and action, which is the embodiment of patriotism. Third, we should inherit and carry forward the excellent cultural tradition of the Chinese nation, which is ideological ties, and can strengthen the spiritual pillar of the national force. The ideological and political education focusing on the cultivation of patriotism education should enrich and broaden the path of patriotism education in addition to the main channel of the ideological and political theory course. First of all, with an emphasis on national interests, build a patriotic education content system. Next, we should preempt the network position to open up new ways of patriotism education. Finally, taking a large event as an opportunity, creates patriotic education environment.

Deng Xiaoping once said,"I am the son of china, I love my country and my people affectionately." Patriotism is the spirit of the theme of Chinese society, and the patriotism education is the key of the ideological and political education. Ideological and political education advocates social psychological sublimation as a patriotic belief, and we should change the patriotic ideas into action. It should based on the principles of national interests, deepening the patriotic emotion, 
enhancing the national self-confidence and pride.

Moral Education is The Foundation.To carry out moral education, we should be in accordance with the guiding ideology, principles, the main contents of the <citizen moral construction implementation outline $>$, which is the promulgation of our country . At the same time we should insist that the dominant orientation of serving the people is the core, and collectivism is the principle, love motherland, love people, love science, love labor, love socialist basic requirement, taking social morality, professional ethics and family virtues as the focal point, making moral education not only adhere to the orientation of socialism ,but also has diversity.

The content and the scope are very wide about the moral education of ideological and political education under the guidance. It includes the spirit of unremitting self-improvement, cultivating self-discipline attitude, the value orientation of honesty and trustworthiness, the principle of human solidarity, hard work, thrift, integrity, and honoring the teacher and respecting his teaching sense of social commitment, helpfulness, honest and so on. In general, the ideological and political education is on the basis of moral education. Moral education is a standard of a judgment about right and wrong(true), the definition of honor and disgrace (good), the distinction between beauty and ugliness (beauty), which need adhere to the Marx doctrine and taking as the guidance of the core values; which need adhere to the fairness and justice and taking as the premise of the interests ; which need adhere to the socialist concept of honor and disgrace and taking as the core of moral values; which need adhere to the humanistic spirit and taking as the fundamental concept of development.

Training Scientific Thinking Mode. The so-called mode of thinking is the subject thinking and the ideas and methods of problem-solving, which is a whole process of thinking and specific forms of thinking activities. The way of thinking is philosophical category, which is the rational cognitive mode. Due to the influence of subjective and objective conditions, a certain way of thinking is always the product of a certain historical era, and it is formed and developed on the basis of a certain practice. As Engels said, "the theoretical thinking of every era, which is the product of history, has different forms and contents in different times." Scientific way of thinking is the relatively abstract concept, we should grasp the essence through the phenomena:

First, the scientific thinking is to explore the rule of seeking truth.Science has many attributes, such as objectivity, accuracy, predictability,etc. But science is the science, the most fundamental attribute is its objectivity. Visible, scientific thinking demands explore the inherent law of the object, so truth is the first prerequisite in scientific thinking. Second,scientific thinking is to follow the law of good thinking. The fundamental mission of scientific thinking is to reveal and reflect the law of the object. But the purpose of revealing and reflecting the rule is to recognize the law, to observe and apply the law. Only by careful exploration of scientific thinking, accurate analysis, rigorous reasoning, effective reasoning, then can find the law of social development and provide the required standard about judging right and wrong, good and evil, beauty and ugliness, which becomes prototype to behave the goodness model. Third, the scientific thinking is the benefit of mankind's aesthetic thinking. The education of scientific thinking inherently requires people to set up the correct outlook on life and values. Under the guidance of such a correct outlook on life and values, which is bound to be another realm, a kind of collective, social, national and human well-being to explore the realm of truth, a realm of life is into the beauty state.

The ideological and political education about training of scientific thinking mode needs to start from the subjective, objective two aspects. One is to guide people to face living practice, everything from reality, seeking truth from facts. Two is to guide people to change their ideas, especially values.Three is to cultivate the spirit of science,in order to form a reasonable way of thinking to 
create a good spiritual atmosphere.The scientific thinking mode under the guidance of ideological and political education is in essential the process of information processing, management and transformation, which is the choice, integration, conversion and regulation of the true, good and beauty.

\section{Summary}

Marxism believed,"truth - seeking activities, goodness and aesthetic activities are basic human activities, only when true subjection,goodness objectification, then people will be able to intuitively confirm human's essential strength in the results of their own behavior, so as to arouse a lofty emotion experience and value. This is the beauty of the dialectical integration of true, goodness and beauty."[7] The aesthetic experience and value will not only stimulate and guide education to build a complete personality life of creativity, and be able to internalize and sublimate the education of "reasonable blend", "appropriate virtue", "image integration", "edutainment" of the humanistic environment. In terms of the fundamental purpose , training goals and main tasks of ideological and political education, we can excavate that, "the ideological and political education is interaction dialectic activities of seeking truth, following good and appreciation beauty,namely, pursuing the inherent unity of the true, goodness and beauty. "[8]True, good, beauty is the ultimate pursuit of the human spirit, which is the highest value of the pursuit of human spirit. As a kind of education of cultivation, shaping, transformation, development, improvement, the ideological and political education always adheres to the value pursuit, and maximize the effectiveness of its humanity by their own practice.

\section{References}

[1] Peng Shuzhi. Study on the historical theory of human civilization communication [J]., 2001.

[2] Lu Youquan. Moral cultivation methods of moral [J]. contemporary youth research, 2008 (8): $1-4$.

[3]Chen Chicheng. Historical materialism and the relationship between man and nature [J]. Journal of Xiamen University: Philosophy and Social Science Edition, 1993 (4): 86-89.

[4]Introduction to Chinese ideology and culture [M]. Northwestern Polytechnical University press, 2002.

[5] CPC Central Committee, State Council, on Further Strengthening and improving the ideological and political education of college students [N][D]., 2004.

[6] The CPC Central Committee, the State Council. The implementation outline of the civil moral construction [N][J]. party building, 2001 (12): 4-7.

[7] Wu Haijiang. Research on Natural Dialectics of science, humanity and freedom [J]., 2004, 9: 024.

[8] Lin, Yuliang. "Inter-subjective Ideological and Political Education in Recent Years- A Review", Journal of Politics and Law, 2015. 